\title{
Electronic Databases for Readers' Advisory Services and Intellectual Access to Translated Fiction Not Originally Written in English
}

\section{Juris Dilevko and Keren Dali}

Electronic databases for readers' advisory services are increasingly prevalent in both public and academic libraries. Librarians rely on these databases to suggest new fiction titles to patrons, many of whom are interested in various types of foreign fiction translated into English. Using a case study approach, this paper examines the NoveList database from the perspective of intellectual access to novels originally written in Russian and subsequently translated into English. The number of subject headings assigned to these novels - as well as the number of accompanying book reviews in the NoveList record for each novel-is compared with the number of subject headings and accompanying book reviews present in the NoveList record for novels originally written in English. Translated Russian novels have substantially fewer subject headings and accompanying book reviews than do novels originally written in English. In addition, existing subject headings are often misleading, erroneous, or inefficient. Such shortcomings may be interpreted ideologically, since they have the effect of isolating and excluding translated foreign literature from the general realm of fiction works originally written in English. Impaired intellectual access to translated fiction in NoveList prevents a complete integration of translated fiction with English-language fiction- a circumstance that may lead librarians and patrons to overlook valuable titles. Careful reading of book reviews to extract contextually relevant keywords from which accurate subject headings can then be created is recommended as a simple way to improve the quantity and quality of subject headings and, more broadly, to strengthen intellectual access to translated fiction.

Juris Dilevko (dilevko@fis.utoronto.ca) is Assistant Professor of Information Studies, and Keren Dali (dali@fis. utoronto.ca) is a Graduate Student of Information Studies, University of Toronto.
Tn the past ten years, there has been a renewed interest in readers' advisory Iservices in both public and academic libraries, and in library education for readers' advisory services. Recent books such as The Readers' Advisory Guide to Genre Fiction by Joyce Saricks (2001) and The Readers' Advisor's Companion, a collection of essays edited by Kenneth Shearer and Robert 
Burgin (2001), are emblematic of this renaissance, as is the Genreflecting series under the general direction of Diana Tixier Herald (2000). The latter includes individual reference volumes designed to help librarians recommend titles in such genres as science fiction, horror, fantasy, Christian fiction, mystery and suspense, adventures and westerns, and historical fiction. As Ricki Nordemeyer (2001) pointed out, many public library systems in the United States and Canada have Web-based readers' advisory home pages. Many others subscribe to electronic databases such as NoveList and What Do I Read Next? to help staff members deal with readers' advisory questions. NoveList is a fee-forservice readers' advisory tool available from EBSCO, consisting of books lists, reviews, and other resources for locating fiction titles. What Do I Read Next? is a similar readers' advisory product available from Gale Thomson.

Fiction, after all, accounts for between $65 \%$ and $75 \%$ of the total circulation in public libraries (Wiegand 2001, 8). Universities also are beginning to realize the importance of providing readers' advisory databases. The library systems of the University of Louisville, the University of Rhode Island, and Murray State University are only three of the rapidly growing number of academic libraries that are making such electronic databases available to students and staff members. (The list of databases provided by the University of Rhode Island library system is available at www.uri.edu/library/reference databases/ref.html [accessed February 17, 2003]; for the University of Louisville, see http://ibrary.louisville.edu/research/hot/path.html [accessed February 17, 2003]; for Murray State University, see www.murraystate.edu/msml/databasesatoz.html [accessed February 17, 2003]). Finally, Dana Watson (2000) discusses how an increasing number of universities with graduate programs in Library and Information Science (LIS) are resurrecting or implementing courses in readers' advisory services. Indeed, Wayne Wiegand (2001) urges all LIS schools to develop such courses.

Why all this interest? People have always liked to read, and the rise of book clubs such as the one initiated by Oprah Winfrey and the development of large and comfortable bookstores, such as Barnes and Noble, Borders, and Chapters, were not inconsequential factors in the explosion of reading as a popular-and even fashionable - activity in the 1990s. In addition, scholars such as Janice Radway (1991), Jane Tompkins (1993), and Catherine Sheldrick Ross $(1991,1995,1999)$ provided a solid intellectual foundation for the argument that so-called pleasure reading of such genres as romances, westerns, and mysteries is a significant activity in the lives of numerous individuals. It is an empowering activity that enables them to develop a better understanding of their respective work and personal worlds and, if necessary, provides them with the strength and encouragement to envision and bring about improvements and changes in their life circumstances, to say nothing of a greater awareness of broad historical, cultural, and social events and forces. At the university and college level, the concept of the "browsing room," where students have access to contemporary and older fiction, either in their dormitory structures or in various designated campus reading locations, is making a comeback. As Virginia Vesper (1997) suggested in an overview of the history and benefits of readers' advisory services in academic libraries, the browsing room is connected with the idea that recreational reading has a significant role to play in students' educational and intellectual development, allowing them to make psychological and philosophical discoveries every bit as important as the ones they make in formal classroom settings.

Many fiction titles are borrowed by individuals who know exactly the type of reading material they want. Many others, however, are unsure of what to read next and turn for assistance and suggestions to librarians, who, in turn, rely on print and electronic tools of the kind mentioned above. Tastes in fiction are by no means monolithic, and so librarians are faced, on a daily basis, with individuals who are interested in a wide variety of themes, topics, authors, and genres. Complicating things even more is the fact that, as recent census data from the United States and Canada reveal, the number of foreign-born individuals as a percentage of the total population in these two countries is increasing significantly. According to the 2000 U.S. Census, $11.1 \%$ of the population was foreign-born (31,107,889 people) (United States Census Bureau 2002); this is an increase from 1990, when $7.9 \%$ of the population $(19,767,316$ people) was foreign-born (United States Census Bureau 1992). According to the 2001 Canadian Census, $18.4 \%$ of the population of Canada was born in foreign countries (Anderssen 2003). In large metropolitan areas, the percentage of foreign-born individuals as a percentage of total population is even higher: Toronto (43.7\%); Miami (40.2\%); Los Angeles (30.9\%); and New York City (24.4\%) (Galloway 2003). In the Borough of Brooklyn, New York City, the foreign-born population is $37.8 \%$ of the total population (United States Census Bureau 2002). Many of these people come from countries such as China, India, Russia, Pakistan, and Mexico, and their primary language of communication is not necessarily English. Moreover, as communities become more diverse, there may be a concomitant rise in interest, on the part of Englishspeaking individuals born in North America, in the societies and cultures of more recently arrived individuals. In effect, increasing awareness of the multicultural fabric may stimulate openness to learning more about these cultures. North American universities and colleges offer more and more courses dealing with world and multicultural literature from a variety of intriguing perspectives, and more and more students are from foreign countries or can claim a multicultural heritage. University and college students are therefore 
important consumers of world and multicultural literature. As Alma Dawson and Connie Van Fleet (2001) make clear, such growing interest - a result of global interdependencehas caught the eye of publishers, who are now producing an increasing number of multicultural titles for a larger and larger audience, and making a profit doing so.

Both public and academic libraries are operating in a multicultural environment, and one way that growing multiculturalism likely will manifest itself in the library realm is through an increase in the number of multicultural fiction titles requested by library patrons. Multicultural fiction may take two forms: fiction originally written in a non-English language and then translated into English, or fiction written in English by individuals who are recent immigrants to the United States or Canada. Within this multicultural environment, it would be strange indeed if readers' advisory services were not affected. In the early 1990s, Susan Jane Freiband (1993) and Ismail Abdullahi (1993) recommended that particular attention be paid to readers' advisory services for multicultural communities. In the early 2000s, Dawson and Van Fleet reiterated this recommendation, pointing out that, although there are increasing numbers of "specialized readers' advisory tools that focus on multicultural literatures individually and collectively" (Dawson and Van Fleet 2001, 259), the "extent to which librarians appreciate and commit to diversity" is often cyclical (Dawson and Van Fleet 2001, 262). The phenomenon of cyclical attention to an issue is not necessarily conducive to maintaining, among librarians, an intellectual environment in which sustained familiarity with multicultural and translated fiction titles exists. In light of this cyclical attention, the permanent memory of electronic readers' advisory databases assumes a real importance.

\section{Purpose of the Study}

As mentioned previously, many public and academic libraries use electronic databases such as NoveList and What Do I Read Next? when providing readers' advisory services. Given the demographic and cultural trends identified above, we wanted to analyze and evaluate the extent to which these databases provide intellectual access to one type of multicultural fiction title-namely, works not originally written in English and subsequently translated into English. Are these databases giving good value when it comes to multicultural and translated fiction?

We chose NoveList to serve as the database for our case study. According to its Web page, NoveList has over 100,000 titles in its database. With " 75,000 full text reviews, over 36,000 subject headings and a complete spectrum of searching options, [it] gives you both the flexibility and power you need to address even your most discriminating readers' questions" (EBSCO Information Services 2002a). About 10,000 records are added annually, and updates are performed monthly. We chose novels originally written in Russian and subsequently translated into English to serve as a proxy indicator of multicultural fiction. The breakup of the Soviet Union and the formation of the Russian Federation raised the visibility of Russian fiction in North America insofar as it has moved away from what Valeria Stelmakh called "ideologically engaged fictional works that employed the socio-political symbols of the "friend-orenemy" type" (Stelmakh 1995, 12) to various types of traditional mass cultural genres such as science fiction, thrillers, mysteries, historical fiction, and romances (Lovell 2000, 134-41), thus drawing growing interest from translators and readers. According to the Index Translationum, there were 854 translations of Russian books into English under the subject heading "Literature" for the period 1970 to 1984, while between 1985 and 2002 there were 1,276 such translations (United Nations Educational, Scientific and Cultural Organization 2003). (Index Translationum is based on Universal Decimal Classification (UDC) numbers. Literature is defined as being UDC field 8, which includes Language, Linguistics, and Literature.)

The development of populous Russian-speaking communities in such metropolitan areas as New York, Los Angeles, and Toronto contributed to the sense that first-, second-, and third-generation Russians are a significant part of the multicultural fabric of North America. In Brooklyn, the third-largest reported ancestral affiliation was Russian in the 2000 census (United States Census Bureau 2002). In Canada, the 2001 census reported 337,960 people of Russian ethnic origin (Statistics Canada 2002). Numerous universities have a wealth of courses where both classic and contemporary Russian fiction are read in English translation. As Aaron Trehub noted, there has been "a resurgence of Russian studies at American universities," especially in the field of Russian language and literature, as measured by the number of dissertations submitted (Trehub 2000, 96-97). David Chroust (2001) observed that, as of March 2000, there were nearly 1.6 million Slavic records in the OCLC database, an ongoing testimony to the vitality of Slavic publishers. While the choice of translated fiction originally written in one language, in this case Russian, will not provide results that can be generalized to other groups of multicultural fiction contained in NoveList, the results nevertheless can illuminate important issues about tendencies within this database.

Access was defined as intellectual access to significant elements of a book (i.e., genre, plot, theme) as represented, first, by subject headings and, second, by the book reviews that accompany many NoveList records. NoveList draws most of its subject headings from the Hennepin County 
Library system. Its book reviews come mainly from only four journals (Booklist, Library Journal, Publishers Weekly, and School Library Journal) (EBSCO Information Services 2002d) and one reference tool (Magill Book Reviews). Subject headings have typically been considered the most important method of intellectual access. According to information on the NoveList Web page, "the major elements of a book . . . are described . . . by the use of subject headings, [which] are used to identify the significant and unique parts of a book. NoveList . . . uses a controlled vocabulary as the basis for its subject headings so that the same word is used to describe the same concept or element. These two factors combine to make subject headings a very powerful method for searching and learning about new books. With over 36,000 subject headings used by NoveList, this section of the title record can be quite robust (note the varied and rich descriptions of the subject headings from Storm Track and Outlander)" (EBSCO Information Services 2002d). Moreover, NoveList states that many of its search strategies "use subject headings as their basis" (EBSCO Information Services 2002d). Although NoveList also offers full-text searching of accompanying book reviews and descriptions, only precise, valid, and consistent subject headings connect an item to similar books, thus placing a particular title in a contextual relationship with other fictional works. Instructional information provided by NoveList warns that, "because reviews do not use controlled vocabulary," this fact "can complicate searching [because] you may need to use several phrases, combinations of words or synonyms for the words you seek" (EBSCO Information Services 2002c). Subject headings are a cornerstone of intellectual access to the contents of a book, and we therefore focus on them in this study. However, despite the fact that the book reviews accompanying fiction titles in NoveList do not use controlled vocabulary, they are searchable and thus do provide access to the contents of a book, so we do not totally neglect book reviews in this study.

\section{Research Questions}

The following research questions were developed. Taken as a whole, these research questions (RQ) attempt to determine the level of intellectual access to one set of translated fiction titles in the readers' advisory database NoveList. They also provide one criterion of evaluation for academic and public libraries considering a subscription to NoveList. Our definition of fiction titles only included novels; shortstory collections were not considered.

RQ-1: How many total subject headings does NoveList assign to novels originally published in Russian and subsequently translated into English?
RQ-2: How many topical subject headings does NoveList assign to novels originally published in Russian and subsequently translated into English?

RQ-3: Is there a difference between the total number of subject headings assigned to translated Russian novels and the total number of subject headings assigned to novels originally published in English?

RQ-4: Is there a difference between the total number of topical subject headings assigned to translated Russian novels and the total number of topical subject headings assigned to novels originally published in English?

RQ-5: Is there a difference between the number of book reviews accompanying translated Russian novels and the number of book reviews accompanying novels originally published in English?

In addition to these five quantitatively based research questions, we wanted to determine whether there were any common problems in the subject headings assigned to translated Russian novels in NoveList. Do the subject headings identify significant and unique parts of a particular book, thus facilitating linkages across similar and related books? Finally, if the quantity and quality of subject headings assigned to translated Russian novels in NoveList leave something to be desired, are there ways to improve the quantity and quality of these subject headings?

\section{Method}

To identify as completely as possible the set of relevant records of Russian language novels translated into English, we employed NoveList's Guided Boolean search function. The reading level was set as "Adult." Search parameters were set as follows: "Russia* AND Translations into English" in the "Subjects" field. A total of 221 records were retrieved in this search. Of these 221 titles, 18 were not originally written in Russian, 82 were short-story collections, and 2 were duplicates. The final set of relevant records thus contains 119 Russian novels translated into English. The search for this set of records was carried out in December 2002.

As our comparison set of novels originally published in English, we chose the titles appearing on six lists: 100 best novels selected by the Board of Modern Library (Random House 1998); American Library Association (ALA) Notable Books, 1990-2002; Booker Prize, 1969-2001; Booklist Editors Choice of Best Fiction, 1995-2001; National Book 
Critics Circle Award, 1975-2001; and Oprah Book Club choices, September 1996-April 2002. These last five lists of award-winning titles are located within the NoveList database (EBSCO Information Services 2002b). Taken together, these six lists present a good cross-section of popular and notable novels originally published in English. After eliminating short-story collections, translated novels, and duplicates, the comparison set of novels originally published in English contained 392 records. Classic English novels were defined as those appearing on the Modern Library Best Novels List. This list contained 99 novels in total, after elimination of 1 translated work. The remaining 293 books were defined as Contemporary English novels. The search for this set of records was done in January 2003.

\section{Results}

To help in answering RQ-1 and RQ-2, translated Russian novels were classified into four categories: Classical (prerevolutionary, or pre-1917, authors); Soviet (authors who wrote in the Soviet period from 1917 to 1991); Émigré (authors who left the Soviet Union at some point in their literary career); and Contemporary (post-Soviet authors). These categories were based on the work of Stephen Lovell (2000), Klaus Mehnert (1983), and Valeria Stelmakh (1998, 2001). Thirty-eight novels are by émigré authors (31.9\%); 32 by classic authors (26.9\%); 28 by Soviet authors $(23.5 \%)$; and 21 by contemporary authors (17.6\%). All subject headings for the 119 novels were grouped into four categories based on Guidelines on Subject Access to Individual Works of Fiction, Drama, Etc., 2d ed., published by the American Library Association (2000). Each subject heading was identified as one of the following: form/genre, character, setting, or topical. (Subject headings assigned by NoveList that indicate whether a book is an award-winner were not counted.) A total of 544 subject headings was identified for the 119 translated Russian novels: 12 character subject headings (2.2\%); 94 setting subject headings (17.3\%); 168 form/genre subject headings (30.9\%); and 270 topical subject headings (49.6\%). The total number of subject headings assigned to each novel ranged from 1 to 19 , with an average of 4.6 subject headings per record. Table 1 provides a breakdown of translated Russian novels according to the number of total subject headings these novels were assigned in NoveList. Because topical subject headings often contain information that is expected to reflect the content of an individual book and because almost half $(49.6 \%)$ of subject headings assigned to translated Russian novels in NoveList were topical subject headings, we focused further attention on topical subject headings. Table 2 provides a breakdown of translated Russian novels according to the number of topical subject headings that these novels were assigned in NoveList.
As shown in table $1,16 \%$ of translated Russian novels are assigned only 1 subject heading, while $53.8 \%$ have between 2 and 5 subject headings and 30.2\% have more than 5 subject headings. Novels in the Contemporary category have more than 5 subject headings at a much greater rate $(61.9 \%)$ than titles in the three other categories (Classical, 25\%; Soviet, 25\%; and Émigré, 21.1\%). The overall situation changes significantly when topical subject headings alone are considered. As shown in table 2, 47.9\% of translated Russian novels have none or only 1 topical subject heading. Fifty-one novels $(42.9 \%)$ have between 2 and 5 topical subject headings, while only 11 novels (9.2\%) have more than 5 topical subject headings. Moreover, novels categorized as Contemporary have 2 or more subject headings at a greater rate $(66.7 \%)$ than do titles categorized as Classical (40.7\%), Soviet (57.2\%), or Émigré (50\%).

While NoveList does not devote much attention and energy to assigning topical subject headings to translated Russian novels, it has a tendency to assign a greater number of subject headings, including topical subject headings, to contemporary novels. These trends are confirmed when the 119 translated Russian novels are categorized according to date of publication. As table 3 indicates, more novels (47.4\%) published prior to 1970 have only 1 subject heading than do novels published after 1970. Only $21.4 \%$ of novels published between 1970 and 1984 and 5.6\% of those published after 1985 have 1 subject heading. A large percentage (43.1\%) of novels published between 1985 and 2002 has more than 5 subject headings. In comparison, only $10.5 \%$ and $10.7 \%$ of novels published prior to 1970 and between 1970 and 1984, respectively, have more than 5 subject headings. As shown in table 4, very few novels, from an overall perspective, have more than 5 topical subject headings, but, of these, almost all (10 out of 11) were published between 1985 and 2002. Similarly, of the 51 translated Russian novels that have between 2 and 5 topical subject headings, 35 (48.6\%) were published between 1985 and 2002.

With regard to RQ-3 and RQ-4, the number of total subject headings and topical subject headings assigned to translated Russian novels by NoveList was compared with the number of total and topical subject headings assigned to novels originally written in English. As shown in table 5, the percentage of all translated Russian novels that has only 1 subject heading $(16 \%)$ is more than five times the percentage of all English novels that have only 1 subject heading (2.6\%). Similarly, while $49.7 \%$ of all English novels have 6 or more subject headings, only $30.2 \%$ of all translated Russian novels have 6 or more subject headings. To paint a starker picture, while 109 English novels (27.8\%) have 8 or more subject headings, only 14 translated Russian novels (11.7\%) have 8 or more subject headings. In general, the same types of trends are evident when the number of total subject headings for classic English novels is compared with the number of total 
subject headings for translated Russian novels published before 1970, and when the number of total subject headings for contemporary English novels is compared with the number of total subject headings for translated Russian novels published after 1970 .

When considering topical subject headings, the discrepancy between translated Russian and English novels is also apparent. As shown in table 6, the percentage of translated Russian novels that have none or only 1 topical subject heading $(47.1 \%)$ is more than three times the percentage of English novels that have none or only 1 topical subject heading $(13.8 \%)$. Similarly, while $27.8 \%$ of English novels have 6 or more topical subject headings, only $9.2 \%$ of translated Russian novels have 6 or more topical subject headings. Finally, while 46 English novels $(11.7 \%$ ) have 8 or more topical subject headings, only 4 translated Russian novels (3.3\%) have 8 or more topical subject headings. Again, the same types of general trends are evident when the number of topical subject headings for classic English novels is compared with the number of topical subject headings for translated Russian novels published before 1970, and when the number of topical subject headings for contemporary English novels is compared with the number of topical subject headings for translated Russian novels published after 1970.

With regard to RQ-5, the number of translated Russian novels that have no accompanying reviews in NoveList is substantially greater $(58.8 \%)$ than the number of novels originally written in English having no accompanying reviews $(20.4 \%)$. See table 7 . That is, 312 of the novels originally written in English $(79.6 \%)$ had at least 1 review, while only 49 of the translated Russian novels $(41.2 \%)$ had at least 1 review. Indeed, while $49.7 \%$ of English language novels have 3 or more accompanying reviews, only $5.9 \%$ of translated Russian novels have 3 or more reviews. The same types of general trends are evident when the number of reviews for classic English novels is compared with the number of reviews for translated Russian novels published before 1970, and when the number of reviews for contemporary English novels is compared with the number of reviews for translated Russian novels published after 1970.

Why is this noteworthy? If there are, overall, fewer available book reviews for translated Russian novels than for novels originally written in English and fewer available book reviews per each translated Russian novel than per each novel originally written in English, then a patron browsing for new fiction titles in NoveList using the fulltext search function has a greater chance of finding those fictional titles, or those groups of fictional titles, that have more accompanying book reviews than books, or groups of books, that do not have accompanying book reviews.

Yet a wide range of reviews is available for translated Russian novels. In fact, the 119 novels generated 762 reviews from library, scholarly, and popular/consumer sources that
Table 1. Categories of Translated Russian Fiction Titles by the Total Number of Subject Headings

\begin{tabular}{lccc}
\hline Category & $\begin{array}{c}\text { 1 Subject } \\
\text { Heading (\%) }\end{array}$ & $\begin{array}{c}\text { 2-5 Subject } \\
\text { Headings (\%) }\end{array}$ & $\begin{array}{c}\text { More than 5 } \\
\text { Headings (\%) }\end{array}$ \\
Classical (32) & $9(28.1)$ & $15(46.9)$ & $8(25)$ \\
Soviet (28) & $2(7.1)$ & $19(67.9)$ & $7(25)$ \\
Émigré (38) & $7(18.4)$ & $23(60.5)$ & $8(21.1)$ \\
Contemporary (21) & $1(4.8)$ & $7(33.3)$ & $13(61.9)$ \\
Total (119) & $19(16)$ & $64(53.8)$ & $36(30.2)$ \\
\hline
\end{tabular}

Table 2. Categories of Translated Russian Fiction Titles by the Number of Topical Subject Headings

\begin{tabular}{lccc}
\hline & $\begin{array}{c}\text { None or 1 } \\
\text { Subject } \\
\text { Heading (\%) }\end{array}$ & $\begin{array}{c}\text { 2-5 Subject } \\
\text { Headings (\%) }\end{array}$ & $\begin{array}{c}\text { More than 5 } \\
\text { Subject } \\
\text { Headings (\%) }\end{array}$ \\
Category & $19(59.4)$ & $10(31.3)$ & $3(9.4)$ \\
Sovical (32) & $12(42.9)$ & $15(53.6)$ & $1(3.6)$ \\
Émigré (38) & $19(50)$ & $17(44.7)$ & $2(5.3)$ \\
Contemporary (21) & $7(33.3)$ & $9(42.9)$ & $5(23.8)$ \\
Total (119) & $57(47.9)$ & $51(42.9)$ & $11(9.2)$ \\
\hline
\end{tabular}

Table 3. Publication Year of Translated Russian Fiction Titles by the Total Number of Subject Headings

\begin{tabular}{lccc}
\hline $\begin{array}{c}\text { Year of } \\
\text { Publication }\end{array}$ & $\begin{array}{c}\text { 1 Subject } \\
\text { Heading (\%) }\end{array}$ & $\begin{array}{c}\text { 2-5 Subject } \\
\text { Headings (\%) }\end{array}$ & $\begin{array}{c}\text { More than 5 } \\
\text { Headings (\%) }\end{array}$ \\
Prior to 1970 (19) & $9(47.4)$ & $8(42.1)$ & $2(10.5)$ \\
1970-1984 (28) & $6(21.4)$ & $19(67.9)$ & $3(10.7)$ \\
1985-2002 (72) & $4(5.6)$ & $37(51.4)$ & $31(43.1)$ \\
Total (119) & $19(16)$ & $64(53.8)$ & $36(30.2)$ \\
\hline
\end{tabular}

Table 4. Publication Year of Translated Russian Fiction Titles by the Number of Topical Subject Headings

\begin{tabular}{lccc}
\hline $\begin{array}{c}\text { Year of } \\
\text { Publication }\end{array}$ & $\begin{array}{c}\text { None or 1 } \\
\text { Subject } \\
\text { Heading (\%) }\end{array}$ & $\begin{array}{c}\text { 2-5 Subject } \\
\text { Headings (\%) }\end{array}$ & $\begin{array}{c}\text { More than 5 } \\
\text { Subject } \\
\text { Headings (\%) }\end{array}$ \\
1970-1984 (28) & $13(68.4)$ & $6(31.6)$ & $0(0)$ \\
1985-2002 (72) & $17(60.7)$ & $10(35.7)$ & $1(3.6)$ \\
Total (119) & $27(37.5)$ & $35(48.6)$ & $10(13.9)$ \\
\hline
\end{tabular}

were indexed in the ProQuest database. Some examples of these sources are World Literature Today; Slavic Review; Slavic and East European Journal; The Russian Review; and The Slavonic and East European Review. Of these 762 reviews, $140(18.4 \%)$ were located in library journals such as Booklist, Library Journal, Publishers Weekly, Choice, and School Library Journal. More importantly, as shown in table 8, 91 translated Russian novels (76.5\%) generated at least 1 review, with 31 novels $(26.1 \%$ ) having between 5 and 10 reviews, and 25 novels (21\%) having more than 10 reviews. Sixty-seven of these novels (56.3\%) were reviewed in at least 
Table 5. Number of Total Subject Headings for English and Translated Russian-Language Titles

\begin{tabular}{|c|c|c|c|c|c|}
\hline & $\begin{array}{c}1 \text { Subject } \\
\text { Heading (\%) }\end{array}$ & $\begin{array}{l}\text { 2-5 Subject } \\
\text { Headings (\%) }\end{array}$ & $\begin{array}{l}\text { 6-7 Subject } \\
\text { Headings (\%) }\end{array}$ & $\begin{array}{l}\text { 8-10 Subject } \\
\text { Headings (\%) }\end{array}$ & $\begin{array}{l}\text { More than } 10 \\
\text { Subject } \\
\text { Headings (\%) }\end{array}$ \\
\hline Novels originally published in English (392) & $10(2.6)$ & $187(47.7)$ & $86(21.9)$ & $71(18.1)$ & $38(9.7)$ \\
\hline Classic novels originally published in English (99) & $4(4)$ & $60(60.6)$ & $21(21.2)$ & $10(10.1)$ & $4(4)$ \\
\hline Contemporary novels originally published in English (293) & $6(2)$ & $127(43.3)$ & $65(22.2)$ & $61(20.8)$ & $34(11.6)$ \\
\hline Russian novels translated into English (119) & $19(16)$ & $64(53.8)$ & $22(18.5)$ & $8(6.7)$ & $6(5)$ \\
\hline Translated Russian fiction published before 1970 (19) & $9(47.4)$ & $8(42.1)$ & $2(10.5)$ & $0(0)$ & $0(0)$ \\
\hline Translated Russian fiction published after 1970 (100) & $10(10)$ & $56(56)$ & $20(20)$ & $8(8)$ & $6(6)$ \\
\hline
\end{tabular}

Table 6. Number of Topical Subject Headings for English and Translated Russian-Language Titles

\begin{tabular}{|c|c|c|c|c|c|}
\hline & $\begin{array}{c}\text { None or } 1 \\
\text { Subject } \\
\text { Heading (\%) }\end{array}$ & $\begin{array}{c}\text { 2-5 Subject } \\
\text { Headings (\%) }\end{array}$ & $\begin{array}{c}\text { 6-7 Subject } \\
\text { Headings (\%) }\end{array}$ & $\begin{array}{l}8-10 \text { Subject } \\
\text { Headings (\%) }\end{array}$ & $\begin{array}{l}\text { More than } 10 \\
\text { Subject } \\
\text { Headings (\%) }\end{array}$ \\
\hline All novels originally published in English (392) & $54(13.8)$ & $229(58.4)$ & $63(16.1)$ & $33(8.4)$ & $13(3.3)$ \\
\hline Classic novels originally published in English (99) & $25(25.3)$ & $57(57.6)$ & $13(13.1)$ & $3(3)$ & $1(1)$ \\
\hline Contemporary novels originally published in English (293) & $29(9.9)$ & $172(58.7)$ & $50(17.1)$ & $30(10.2)$ & $12(4.1)$ \\
\hline Russian novels translated into English (119) & $56(47.1)$ & $52(43.7)$ & $7(5.9)$ & $1(0.8)$ & $3(2.5)$ \\
\hline Translated Russian fiction published before 1970 (19) & $13(68.4)$ & $6(31.6)$ & $0(0)$ & $0(0)$ & $0(0)$ \\
\hline Translated Russian fiction published after 1970 (100) & $43(43)$ & $46(46)$ & $7(7)$ & $1(1)$ & $3(3)$ \\
\hline
\end{tabular}

Table 7. Number of Reviews in NoveList for Translated Russian Novels and Novels Originally Published in English

\begin{tabular}{|c|c|c|c|c|c|c|}
\hline Type of fiction & $\begin{array}{c}\text { No reviews } \\
(\%)\end{array}$ & $\begin{array}{l}\text { One review } \\
\text { reviews (\%) }\end{array}$ & $\begin{array}{c}\text { Two } \\
\text { reviews (\%) }\end{array}$ & $\begin{array}{c}\text { Three } \\
\text { reviews (\%) }\end{array}$ & $\begin{array}{c}\text { Four } \\
\text { reviews (\%) }\end{array}$ & $\begin{array}{c}\text { Five } \\
\text { reviews (\%) }\end{array}$ \\
\hline All fiction originally published in & & & & & & \\
\hline English (392) & $80(20.4)$ & $64(16.3)$ & $53(13.5)$ & $164(41.8)$ & $28(7.1)$ & $3(0.8)$ \\
\hline Classic English fiction (99) & $62(62.6)$ & 29 (29.3) & $8(8.1)$ & $0(0)$ & $0(0)$ & $0(0)$ \\
\hline Contemporary English fiction (293) & $18(6.1)$ & 35 (11.9) & $45(15.3)$ & $164(56)$ & $28(9.6)$ & $3(1)$ \\
\hline All translated Russian fiction (119) & $70(58.8)$ & $28(23.5)$ & $14(11.8)$ & 7 (5.9) & $0(0)$ & $0(0)$ \\
\hline $\begin{array}{l}\text { Translated Russian fiction published } \\
\text { before } 1970 \text { (19) }\end{array}$ & 15 (78.9) & $3(15.8)$ & $1(5.3)$ & $0(0)$ & $0(0)$ & $0(0)$ \\
\hline $\begin{array}{l}\text { Translated Russian fiction published } \\
\quad \text { after } 1970 \text { (100) }\end{array}$ & $55(55)$ & $25(25)$ & 13 (13) & $7(7)$ & $0(0)$ & $0(0)$ \\
\hline
\end{tabular}

Table 8. Availability of Reviews for Translated Russian Novels in Reviewing Sources Indexed by ProQuest

\begin{tabular}{|c|c|c|c|c|}
\hline Type of fiction & No reviews (\%) & $1-4$ reviews (\%) & $5-10$ reviews (\%) & $\begin{array}{c}\text { More than } \\
10 \text { reviews (\%) }\end{array}$ \\
\hline All translated Russian fiction (119) & $28(23.5)$ & $35(29.4)$ & $31(26.1)$ & $25(21)$ \\
\hline Translated Russian fiction published before 1970 (19) & $6(31.6)$ & $6(31.6)$ & $3(15.8)$ & $4(21.1)$ \\
\hline Translated Russian fiction published 1970-1984 (28) & $18(64.3)$ & $4(14.3)$ & $1(3.6)$ & $5(17.9)$ \\
\hline Translated Russian fiction published 1985-2002 (72) & $4(5.6)$ & $25(34.7)$ & $27(37.5)$ & $16(22.2)$ \\
\hline
\end{tabular}

one library journal. The fact that 91 translated Russian novels $(76.5 \%)$ generated at least 1 review in an indexed journal publication is encouraging.

On the other hand, as mentioned above, only 49 translated Russian novels (41.2\%) have at least 1 book review associated with their record in NoveList. Despite the ready availability of book reviews, NoveList often fails to incorporate them into its records of translated Russian novels, possi- bly because NoveList draws the vast majority of its reviews from only four journals: Booklist, Library Journal, Publishers Weekly, and School Library Journal (EBSCO Information Services, 2002d). Librarians and patrons using NoveList thus have a greater chance of intellectually accessing novels originally written in English than they do intellectually accessing translated Russian novels, not only because of wide discrepancies in the quantity of subject headings, but also because of 
wide discrepancies in the number of book reviews that accompany these two types of novels. For the producers of NoveList, reliance on only four journals for reviews may be a wise financial decision insofar as use of reviews from additional sources may entail seemingly burdensome expenditures for reprint permissions. At the same time, however, such a decision also has the effect of substantially reducing intellectual access to translated fiction.

\section{Discussion}

On the whole, translated Russian novels are assigned fewer total and fewer topical subject headings than novels originally written in English. In light of the demographic and cultural trends identified above, this numerical discrepancy in subject headings - especially topical subject headingsshould be cause for some concern, since it points to the inability of the developers of NoveList to adequately provide intellectual access to an important and rapidly expanding component of multicultural literature: translated foreign novels. According to Natasha Wimmer, despite the fact that only about $6 \%$ of all books translated worldwide are translations from foreign languages into English, many editors at publishing houses in the United States believe that "there's been an upturn in the past seven or eight years" and that "the bestseller lists and publishing programs of the major houses" will become as international as the ones in Europe (Wimmer 2001, 71-72). Moreover, many university presses and small independent presses have a substantial and ever-increasing commitment to translated fiction (Wimmer 2001, 73).

If the lack of subject headings assigned to translated Russian novels in NoveList is any indication, foreign literature translated into English is likely to remain intellectually isolated and excluded from the general realm of fiction works originally written in English. In other words, an individual searching for a new fiction book to read using the NoveList database likely will not be informed by the database that there are Russian novels that meet her or his reading interests. For example, five novels by Fyodor Dostoevsky (The Adolescent, The Friend of the Family, The Idiot, Netochka Nezvanova, and A Raw Youth), The Master and Margarita by Mikhail Bulgakov, and seven novels by Vladimir Nabokov (Ada, Bend Sinister, The Eye, Invitation to a Beheading, Laughter in the Dark, Mary, and Glory) are assigned only one form/genre subject heading each. The lack of topical subject headings means that NoveList fails to relate these Russian novels to other fictional works with the same topics, themes, and ideas. In order to intellectually integrate foreign language literature coming from a specific country into the entire collection of fiction indexed in NoveList and to maintain integrity and intellectual interconnections within the subcollection of foreign literature itself, improved subject access is required.
Beyond the circumstance of insufficient topical subject headings, there are four additional problem areas: complete lack of subject headings; redundant or inefficient subject headings; inconsistent subject headings; and wrong, misleading, or ambiguous subject headings. As mentioned above in the Method section, searching in the NoveList "Subjects" field ultimately generated 119 translated Russian novels that were used as the basis of this study. However, when a subsequent search was conducted in all available fields, an additional 29 translated Russian novels were retrieved. Of these 29 titles, 9 did not have any subject headings, 18 others did not have a heading subdivision for "Translations into English," and 2 titles had other inconsistencies. Five more records for translated Russian novels were found completely by accident. In all 5 of these cases, the word Russia* was not present anywhere in the record. No doubt there are many more "missing" records, but the examples discussed here highlight the problem of the lack of subject headings. In practical terms, this means that many authors and works of potential interest are hidden from users of NoveList. For instance, among the translated Russian authors who would not be identified through a search of only the "Subjects" field are Daniil Granin, Konstantin Fedin, and Aleksandr Goncharov.

With regard to redundant and inefficient subject headings, the Guidelines on Subject Access to Individual Works of Fiction, Drama, etc. recommends that indexers and catalogers "never assign both broader and narrower terms to the same work" (American Library Association 2000, 4). Both broader and narrower subject headings applied to the same work with no special justification for doing so are deemed redundant or inefficient. Moreover, two or three synonymous terms, which express the same topic or notion, do not add to the book description, and do not improve access to its content, also are considered inefficient, especially when they are assigned instead of other subject headings that could be more reflective of the intellectual content of a book and therefore more useful to potential patrons. For example, the two subject headings assigned Julia Voznesenskaya's The Women's Decameron, "Russian émigré fiction - 20th century - Translations into English" and "Russian fiction - 20th century - Translations into English," could be replaced by the single subject heading "Russian émigré literature in the twentieth century - Translations into English." Similarly, the three subject headings assigned Fyodor Dostoevsky's The House of the Dead, "Prisons - Siberia," "Prisoners - Siberia," and "Political prisoners - Siberia," could be replaced by the single subject heading "Political prisoners - Siberia."

Inconsistent subject headings, either among works by the same author or among works with related themes and plots, are also a significant problem in NoveList. The most obvious inconsistencies are observed in form/genre subject headings. For instance, works by such émigré authors as Yuz Aleshkovsky, Nina Berberova, Vladimir Nabokov, Aleksandr 
Table 9. Suggested Subject Headings for Dostoevsky's The Idiot Using Contextually Relevant Words and Phrases Extracted from Various Reviewing Sources

\begin{tabular}{|c|c|c|c|}
\hline $\begin{array}{l}\text { Type of } \\
\text { Subject } \\
\text { Heading } \\
\text { Form or Genre }\end{array}$ & $\begin{array}{l}\text { Words and Phrases } \\
\text { from Magill Book } \\
\text { Reviews } \\
\text { Russian }\end{array}$ & $\begin{array}{l}\text { Words and Phrases } \\
\text { from Reference Guide to } \\
\text { Russian Literature }\end{array}$ & $\begin{array}{l}\text { Suggested Subject Headings } \\
\text { Russian fiction - 19th century - Translations into English } \\
\text { Psychological fiction, Russian - 19th century - Translations into } \\
\quad \text { English } \\
\text { Historical fiction, Russian - 19th century - Translations into } \\
\quad \text { English }\end{array}$ \\
\hline Setting & $\begin{array}{l}\text { Russia } \\
\text { St. Petersburg }\end{array}$ & St. Petersburg & Saint Petersburg (Russia) - Social life and customs - 19th century \\
\hline Topical & $\begin{array}{l}\text { epilepsy } \\
\text { humanity } \\
\text { nobleman } \\
\text { love and contempt } \\
\text { friends } \\
\text { kept woman } \\
\text { innocence } \\
\text { suffering } \\
\text { returning good for evil } \\
\text { scandals }\end{array}$ & $\begin{array}{l}\text { epileptic } \\
\text { ideal of human perfectibility } \\
\text { innocent and saintly } \\
\text { princely family } \\
\text { woman of questionable reputation } \\
\text { triangle } \\
\text { crisis [in society] } \\
\text { chaos and disorder } \\
\text { apocalyptic atmosphere } \\
\text { human alienation from nature } \\
\text { society ... on the } \\
\quad \text { brink of collapse }\end{array}$ & $\begin{array}{l}\text { Social problems - Saint Petersburg (Russia) - 19th century } \\
\text { Nobility - Russia - 19th century } \\
\text { Scandals - Russia - 19th century } \\
\text { Triangles (Interpersonal relations) - Russia } \\
\text { Courtesans - Russia - 19th century } \\
\text { Male friendship - Russia } \\
\text { Epileptics - Russia } \\
\text { Mentally ill } \\
\text { Suffering } \\
\text { Innocence (Psychology) } \\
\text { Idealism (Personal trait) } \\
\text { Good and evil } \\
\text { Platonic love } \\
\text { Humanity }\end{array}$ \\
\hline
\end{tabular}

Solzhenitsyn, Edward Topol, and Vladimir Voinovich are not assigned a heading for "Russian émigré fiction - 20th century - Translations into English," whereas the works of Vasily Aksenov and Sergei Dovlatov are identified as being by Russian émigré writers. Moreover, subject headings are not always consistent among works by the same authors. Only one (out of four) of Aksenov's books and one (out of two) of Dovlatov's books are provided with subject headings for émigré fiction. Other examples of inconsistency are not hard to find. Whereas books by Aleshkovsky, Dovlatov, and Viktor Pelevin (Homo Zapiens and Omon Ra) are assigned subject headings that read "Satirical fiction, Russian" with subsequent subdivisions, Pelevin's The Life of Insects, Alexander Zinoviev's Homo Sovieticus, and Voinovich's The Anti-Soviet Soviet Union are identified as Russian satire. Whereas Solzhenitsyn's Cancer Ward, Lydia Zinovieva-Annibal's The Tragic Menagerie, and Abram Tertz's Goodnight! are given subject headings that read "Autobiographical novel," Ivan Turgenev's Spring Torrents and Yevgeny Yevtushenko's Don't Die before You're Dead are assigned subject headings that read "Russian autobiographical novels - Translations into English." In addition, the same main headings (e.g., "Russian fiction" and "Satirical fiction, Russian") may or may not have chronological subdivisions and a subdivision of "Translations into English."

Finally, subject headings assigned by NoveList occasionally grant potential readers an entirely erroneous impression of a book's content. Take, for instance, Pelevin's The Life of
Insects, which has "Insects - Crimea," "Mosquitoes Crimea," "Resorts - Crimea," and "Americans in Crimea" as four of its subject headings. Insofar as the novel is an allegory, these subject headings bear no resemblance to the philosophical and cultural themes and topics of the book. Relying on the subject headings assigned by NoveList, an unwary North American reader may conclude that Pelevin's book is suitable for tourists traveling to famous Crimean resorts - a book from which the reader can expect to learn a number of useful tips employed by native Russians in Crimea to protect themselves from obnoxious and harmful insects. Alternatively, the reader could anticipate finding a number of amusing stories involving insects that pester Americans on holiday in Crimea.

Similarly, Yuri Buida's The Zero Train is not, fundamentally, about trains, railroad stations, and mentally ill men tracked by secret service agents, as four out of its five topical subject headings suggest. Rather, the train is a metaphor for "a life without purpose" in a totalitarian state (Phelan and McDowell 2001, 17) or "a symbol of history, careening unstoppably according to the laws of Marxism" (Massie 2001, 15), and the railway line itself is "the Party Line, to be obeyed, never questioned” (Massie 2001, 15). In essence, the work is a parable about the Stalinist era in the Soviet Union, with its forced labor camps, pervasive fear (Massie 2001, 15), hypocritical, "faceless" authorities, "oppressions," and "daily humiliations and deprivations" where "human existence depends on the maintenance of the repetitive and 
Table 10. Suggested Subject Headings for Dovlatov's The Suitcase Using Contextually Relevant Words and Phrases Extracted from Various Reviewing Sources

\begin{tabular}{|c|c|c|c|c|}
\hline $\begin{array}{l}\text { Type of } \\
\text { Subject } \\
\text { Heading }\end{array}$ & $\begin{array}{l}\text { Words and Phrases } \\
\text { from Magill Book } \\
\text { Reviews and The } \\
\text { Atlantic }\end{array}$ & $\begin{array}{l}\text { Words and Phrases } \\
\text { from Publishers } \\
\text { Weekly and Library } \\
\text { Journal }\end{array}$ & $\begin{array}{l}\text { Words and Phrases } \\
\text { from Review of } \\
\text { Contemporary Fiction } \\
\text { and Reference Guide } \\
\text { to Russian Literature }\end{array}$ & $\begin{array}{l}\text { Suggested Subject } \\
\text { Headings }\end{array}$ \\
\hline \multirow[t]{6}{*}{ Form or Genre } & Soviet Union & ironic humor & Russian literature & $\begin{array}{l}\text { Satirical fiction, Russian - 20th } \\
\text { century - Translations into } \\
\text { English }\end{array}$ \\
\hline & New York & seriousness & humorous & $\begin{array}{l}\text { Russian émigré literature in the } \\
\text { 20th century - } \\
\text { Translations into English }\end{array}$ \\
\hline & autobiographical & $\begin{array}{l}\text { regard } \ldots \text {. with .... a } \\
\text { jaundiced eye }\end{array}$ & social and political commentary & $\begin{array}{l}\text { Autobiographical fiction, Russian } \\
\text { - 20th century - Translations } \\
\text { into English }\end{array}$ \\
\hline & genealogical story & Soviet Union & autobiographically & $\begin{array}{l}\text { Russian - American literature - } \\
\text { United States - 20th century }\end{array}$ \\
\hline & seriocomic nonsequiturs & comic and absurd & "memoir novels" & Irony \\
\hline & $\begin{array}{l}\text { satirical } \\
\text { witty }\end{array}$ & nonconformists & $\begin{array}{l}\text { émigré } \\
\text { absurdist [account] }\end{array}$ & Understatement \\
\hline \multirow[t]{3}{*}{ Setting } & Soviet Union & Soviet Union & USSR & $\begin{array}{l}\text { Soviet Union - Social life and } \\
\text { customs }\end{array}$ \\
\hline & Queens, New York & Russia & & $\begin{array}{l}\text { Soviet Union - Social conditions } \\
\text { Queens (New York, N.Y.) }\end{array}$ \\
\hline & & & & $\begin{array}{l}\text { United States - Emigration and } \\
\quad \text { immigration } \\
\text { Nineteen sixties } \\
\text { Nineteen seventies }\end{array}$ \\
\hline \multirow[t]{8}{*}{ Topical } & fractured life & $\begin{array}{l}\text { woeful failing of Soviet } \\
\text { socialism }\end{array}$ & emigrating from the USSR & Daily life - Soviet Union \\
\hline & émigré & emigrating & $\begin{array}{l}\text { disorganization and confusion } \\
\text { [society] }\end{array}$ & Frustration \\
\hline & frustrations & longing for his mother country & ordinary Soviet citizen & $\begin{array}{l}\text { Drinking of alcoholic beverages - } \\
\text { Soviet Union }\end{array}$ \\
\hline & nobody is ever sober & emigrated & drinking & Dissenters - Soviet Union \\
\hline & nostalgia & dedicated drinkers & miserable . . . living conditions & Nostalgia \\
\hline & Soviet life & & miserable [Soviet people] & $\begin{array}{l}\text { Russian Americans - New York } \\
\text { (N.Y.) }\end{array}$ \\
\hline & antihero & & despaired ... in pain & $\begin{array}{l}\text { Immigrants - Russian - United } \\
\text { States }\end{array}$ \\
\hline & & & & Antiheroes \\
\hline
\end{tabular}

aimless" and where "feeling and thought are displaced by worship of the mechanical and industrial" (Phelan and McDowell 2001, 17). Or, as Massie (2001) suggested, it is a parable about one's suppressed personality, emptiness, and inability to enjoy freedom when it is finally granted.

\section{Recommendations}

Given the evident shortcomings in NoveList subject headings, is there a practical way to rectify the situation? Improved subject access to fiction has long been a desire of librarians and scholars (e.g., Copeland 1995; Sapp 1986). Clare Beghtol $(1989,1990)$ explained that one reason that subject access for fictional works has lagged behind subject access to scientific works is that "classification systems have not been generally adopted for content elements of primary works of fiction," and those that have been developed suffer because they adhere to the principle of "classification-by-creator" instead of "classification-by-subject” (Beghtol 1989, 134). Beghtol (1994) and Judith Ranta (1991) have suggested that literary criticism can help indexers assign subject headings at both a denotative and connotative level, thus alleviating the type of subjectivity found by Jarmo Saarti (2002) in a study of the consistency of subject indexing of novels by librarians and members of the public. Christine DeZelar-Tiedman argued that "publisher-supplied copy from dust jackets and the backs of books usually provide[s] sufficient information to apply subject headings to individual works of fiction, drama, etc." (DeZelar-Tiedman 1996, 207-8). Guidelines on Subject 
Table 11. Suggested Subject Headings for Baranskaya's A Week Like Any Other Using Contextually Relevant Words and Phrases Extracted from Various Reviewing Sources

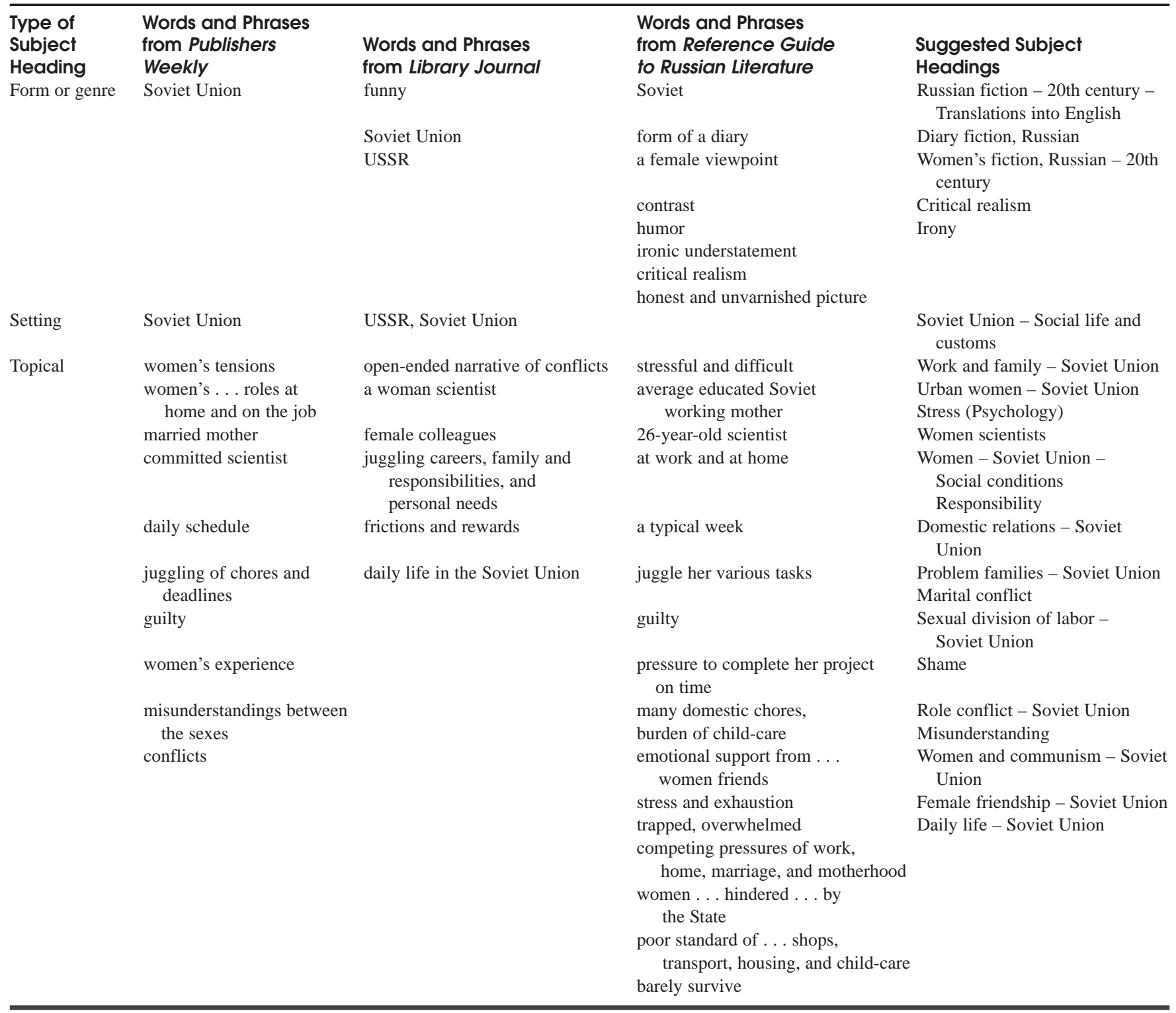

Access to Individual Works of Fiction, Drama, etc. notes that both dust-jacket information and book reviews are "a good source of information for determining what a given work [of fiction] is about" on a factual and thematic level (American Library Association 2000, 47). Indeed, Susan Hayes has demonstrated that "[c]riticism, whether popular, i.e., book or play reviews, or literary, i.e., scholarly articles and monographs, [is] widely available, so the feasibility of using criticism in the subject analysis of fiction [is] not contra-indicated by any dearth of critical material" (Hayes 2001, 91). She remarked, further, that popular criticism is especially useful insofar as the language of popular criticism can more readily be translated into the terminology of Library of Congress Subject Headings (LCSH).

As seen in table 8, 76.5\% of the 119 translated Russian novels under study here were reviewed at least once. Clearly, reviews are available and they could form the raw material for the creation of valuable subject headings, which could enhance intellectual access to translated Russian novels, or any fictional work, in NoveList. As a sample of the kind of information that can be derived from book reviews, we selected four translated Russian novels where the subject headings assigned by NoveList were either minimal or misleading. The selected novels were (with NoveList subject 
Table 12. Suggested Subject Headings for Pelevin's The Life of Insects Using Contextually Relevant Words and Phrases Extracted from Various Reviewing Sources

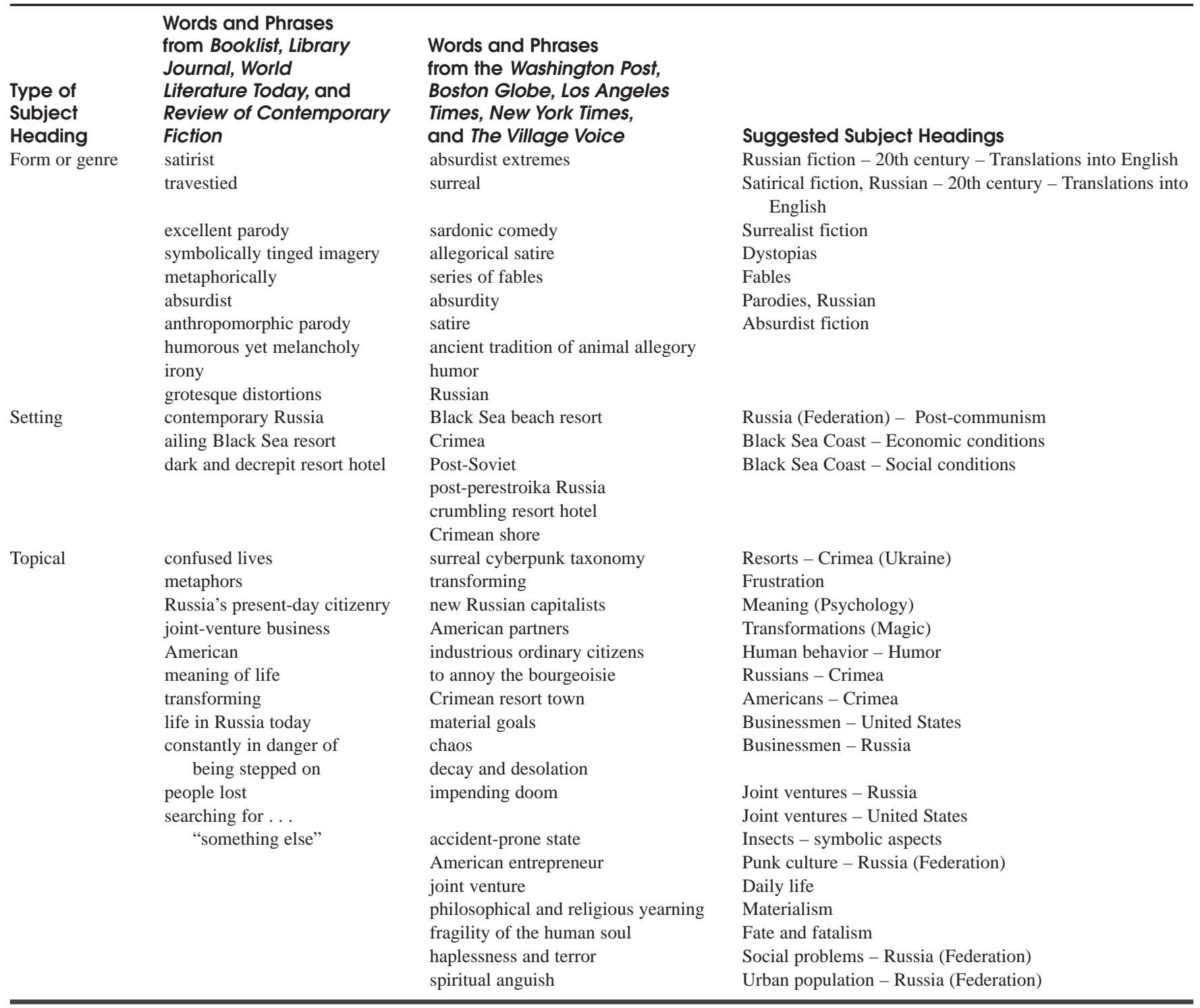

headings in parentheses): Fyodor Dostoevsky's The Idiot ("Russian fiction - 19th century - Translations into English"); Sergei Dovlatov's The Suitcase ("Satirical fiction, Russian 20th century - Translations into English"); Natalya Baranskaya's A Week Like Any Other ("Russian fiction - 20th century - Translations into English”); and Viktor Pelevin's The Life of Insects ("Russian satire - 20th century - Translations into English," "Resorts - Crimea," "Americans in Crimea," "Insects - Crimea," Mosquitoes - Crimea," "Russians in Crimea," and "Crimea"). We then used a variety of popular book review sources to extract key words indicating both denotative and connotative elements, and then, adapting these words and ideas to comply with LCSH rules (Library of Congress 2002; Library of Congress Cataloging Policy and Support Office 2002; Library of Congress Cataloging Policy and Support Office 1996), Olderr's Fiction Subject Headings: A Supplement and Guide to the LC Thesaurus (1991), and the Guidelines on Subject Access to Individual Works of Fiction, Drama, etc. (American Library Association 2000), created form/genre, setting, and topical subject headings. The results are presented in tables 9-12. The appendix at the end of this article presents the sources for book reviews.

As these four tables indicate, a well-rounded picture of the intellectual parameters of each novel emerges from the 
assigned subject headings. From a theoretical perspective, then, it is possible to read a range of book reviews, extract key words and phrases from those reviews, and translate them into a rich portrait of the "aboutness" of a given fictional work (Hayes 2001, 93). In addition, book reviews sometimes provide information about how a particular title is related to other writers and other fictional works, e.g., whether Book A is stylistically or thematically similar to Book B. For instance, in the case of book reviews for Pelevin's The Life of Insects, reviewers invoke the names of such authors as Nikolai Gogol, Franz Kafka, Karel Capek, Ivan Turgenev, Edgar Allan Poe, and Anton Chekhov, pointing out how Pelevin follows in the traditions established by those writers. Reviewers point out that various episodes of Pelevin's The Life of Insects bear resemblance to Gustave Flaubert's Madame Bovary, George Orwell's Animal Farm, William Blake's The Fly, Mikhail Bulgakov's The Master and Margarita, and the character Estragon in Samuel Beckett's Waiting for Godot, not to mention scenes from some of his own earlier novels such as The Yellow Arrow, Omon Ra, and The Blue Lantern. Such references to other writers and other fictional works provide an opportunity for indexers to investigate the subject headings that have been assigned to the mentioned works and consider applying them as well to The Life of Insects, thereby creating intellectual linkages between Pelevin and other European and American writers.

To be sure, this is not a task that can be accomplished in a few minutes. Problems associated with time constraints, a shortage of personnel, and commitment must be overcome. In addition, for fiction translated from languages originally written in non-Romanized scripts (e.g., Cyrillic), searching for reviews, on databases such as ProQuest, from which to draw information about translated novels is often complicated by variant forms of author names (transliterated versus Anglicized forms). Yet, as Gunnar Knutson reported about a study conducted at an academic library in Illinois, the circulation frequency of social science essay collections with additional subject headings was greater (although not statistically significantly so) than the circulation frequency of titles without such enhanced subject headings: "by three different measures of local circulation, the subject-enhanced records accounted for about half of all use even though they represented only a third of the books" (Knutson 1991, 77). In addition, (Mary Dabney Wilson et al. 2000), studying whether an increase in the number of subject headings assigned to fiction titles increases the circulation of those titles at an academic library in Texas, found intriguing (although not statistically significant) evidence that a small set of books with 7 assigned subject headings had, on average, 4.69 circulations per item in the period 1994 to 1998, while titles with fewer subject headings had between 2 and 3 circulations per item in the same period. Accordingly, there is some evidence that an increase in the number of subject headings plays a role in increasing the circulation statistics for both fiction and nonfiction titles. The extra time needed to create additional subject headings may therefore lead many more readers to discover books with additional subject headings; circulation of these titles may therefore rise.

\section{Conclusion}

As Sanford Berman has observed with regard to multicultural materials, an insufficient number of subject access points makes a work "invisible" to potential users, in effect creating "bibliocide by cataloging" (Berman 1992, 132-33). Databases such as NoveList are key components of readers' advisory services, since librarians frequently use them to recommend new titles to patrons. Although NoveList is a powerful tool that contains much valuable information and robust searching capabilities, the deficiencies identified in this article suggest that NoveList has the effect of making translated novels less visible-from the perspective of intellectual access-than novels originally written in English because translated novels have fewer subject headings and fewer accompanying reviews than novels originally written in English. Less intellectual visibility, in many cases, is tantamount to Berman's notion of invisibility. The intellectual invisibility of translated novels in the NoveList database is particularly troubling when the United States and Canada are becoming increasingly diverse and multicultural. This invisibility isolates and excludes translated literature from the general realm of fiction works originally written in English such that an individual searching for a new book to read and using the NoveList database to do so would likely not become aware of translated fiction titles. Inadequate intellectual access to translated fiction in NoveList prevents a complete integration of translated fiction with English-language fiction. NoveList contributes to this isolation by having a very small number of subject headings for translated Russian novels (in comparison with the number of subject headings for novels originally written in English) and by including only a very small number of book reviews in each record despite the ready availability of additional book reviews for these titles in other sources. On the one hand, NoveList states that its subject headings are a significant means of accessing new fiction titles, and that many of its search strategies are based on subject headings. On the other hand, it fails to provide a sufficient quantity of meaningful subject headings for translated Russian novels. Additional research on other sets of translated fiction (e.g., Chinese into English, Swedish into English, Italian into English) also should be carried out using the same general methodological approach discussed in this article.

As discussed above, book reviews are an excellent and readily accessible source for developing subject headings. Although the process of creating additional subject headings 
in this way (or any other way) for translated fiction titles may be looked upon as time-consuming and labor-intensive by some, failure to undertake such a process can be construed as an ideological choice that, inadvertently or not, suggests that fiction originally not written in English is somehow less noteworthy than fiction that is originally written in English. The developers of electronic databases such as NoveList that purport to offer unparalleled access to fiction titles and that help librarians offer readers' advisory services should be aware that a lack of subject headings for certain classes of fiction (in this case, translated Russian novels) hinders intellectual access to such fiction. In effect, it ghettoizes such fiction by not providing links to other more mainstream titles. But, as Leonard Wertheimer observed, "the multilingual part of the library must be an oasis, not a ghetto" (Wertheimer 1991, 381-82). What is true for the collection of books in a tangibly real public library location should also be true for the ephemeral realm of digital libraries and databases. For a database such as NoveList whose aim is to encourage exploration and discovery of new unread titles, a situation that perpetuates ghettoization of fiction is, to say the least, ironic.

Librarians rely on electronic tools such as NoveList when offering readers' advisory services. But this reliance can often turn into overreliance and also can lead librarians to dismiss some of the philosophical consequences of shortcomings in readers' advisory databases such as the ones identified in this article. Even though readers' advisory services have always prided themselves on giving the final choice of reading matter to individual patrons based on their expressed (and different) needs, it has long been recognized that, from a historical perspective, readers' advisory work was part of the flourishing adult education movement in the 1920s and 1930s (Lagemann 1989), where individuals were given "systematic" reading plans so that they could improve themselves and their position in life through self-education (Flexner and Edge 1934, 3-6, 37, 51). This self-education was to come through purposefully working one's way through a list of selected books carefully prepared by a librarian who hoped that, collectively, the books would expand the reader's intellectual and cultural horizons (Wiegand 1999, 4-6). On a more theoretical plane, readers were not only to be improved through books, but they were to become conventional, orderly, and placed into "a new mode of regulation capable of ensuring labor discipline and forging a market for consumer products . . ." (Luyt 2001, 443). As Michael Harris suggested, "if the common man could be induced to read the 'best' books, he would be more inclined to be conservative, patriotic, devout, and respectful of property" (Harris 1973, 2511). The public library in the early twentieth century can therefore be seen, following Dee Garrison (1979), as part of “an urban reform movement of moral uplift, initiated by elements of the middle and upper classes and intended to pro- mote social stability through the weakening of class conflict" (Garrison 1979, 223).

The heritage of readers' advisory services is therefore fraught with complexities. Ideologically, one could argue that, at the same time as they recommend books, readers' advisory services unfairly exclude books from the consideration of patrons relying on such services because they do not create a level playing field (i.e., the same number of subject headings, the same number of accompanying book reviews) for all fiction titles. The reader does not have a fair and equal chance of selecting any given book. Some books are privileged because of a greater number of subject headings or accompanying reviews; others are not. In the end, whether such privileging (or de-privileging) is deliberate or not, or whether it occurs because of librarian bias or arrogance, inadequate subject headings, or gaps in electronic indexing, does not matter. The de-privileging, simply put, has occurred. The reader does not have the possibility of choosing a certain book or books because that choice has been withheld from him or her by a readers' advisory service, in this case NoveList. As the data presented here suggests, intellectual access to translated Russian novels is problematic in NoveList. Readers making use of NoveList are not given as much opportunity to be presented with translated fiction works as they are to be presented with fiction originally written in English. NoveList privileges intellectual access to some books (i.e., fiction originally written in English) while inhibiting intellectual access to others (i.e., translated fiction). Ideologically speaking, NoveList, in its own way, perpetuates the type of elitism discussed by Harris (1973) and Garrison (1979).

In light of this, librarians should make a practice of reading fiction titles and reviews as widely and extensively as possible in order to fill the numerous intellectual gaps in electronic readers' advisory tools. For multicultural fiction titles, two invaluable sources of information are World Literature Today: The Journal and World Literature Today: The Magazine, both of which are edited and produced at the University of Oklahoma. For translated Russian fiction specifically, a tool such as the Reference Guide to Russian Literature (1998) can provide reviews for a large number of books by a variety of classical and contemporary authors. Reliance on electronic tools such as NoveList is a convenient and easy approach to readers' advisory service, but this reliance also can obscure important philosophical issues such as equity in intellectual access with regard to translated fiction. Such reliance also can help to create a climate of intellectual complacency among readers' advisory librarians who may feel that, given the obvious extent and power of NoveList, developing in-depth and first-hand expertise about a wide range of fiction outside their own immediate area of reading interest would be superfluous. 


\section{Works Cited}

Abdullahi, Ismail. 1993. Multicultural issues for readers' advisory services. Collection Building 12 (3/4): 85-88.

American Library Association. Association for Library Collections and Technical Services. Cataloging and Classification Section. Subject Analysis Committee. Subcommittee on the Revision of the Guidelines on Subject Access to Individual Works of Fiction, Drama, etc. 2000. Guidelines on subject access to individual works of fiction, drama, etc., $2 \mathrm{~d}$ ed. Chicago: ALA.

Anderssen, Erin. 2003. Immigration shifts population kaleidoscope. The Globe and Mail (Jan. 2): A6.

Beghtol, Clare. 1989. Access to fiction: A problem in classification theory and practice. Part I. International Classification 16 (3): 134-40.

1990. Access to fiction: A problem in classification theory and practice. Part II. International Classification 17 (1): 21-27.

- 1994. The classification of fiction: The development of a system based on theoretical principles. Metuchen, N.J.: Scarecrow.

Berman, Sanford. 1992. Things are seldom what they seem: Finding multicultural materials in library catalogs. In Alternative library literature, 1990-91: A biennial anthology, ed. Sanford Berman and James Philip Danky, 132-36. Jefferson, N.C.: McFarland.

Chroust, David Zdeněk. 2001. Slavic-language material in OCLC and the search for matching records: Reconsidering an overlooked problem. Slavic \& East European Information Resources 1 (4): 41-67.

Copeland, Jud H. 1995. Accessing French fiction in academe: A case study in "bibliocide." Current Studies in Librarianship 19 (spring/fall): 24-29.

Dawson, Alma, and Connie Van Fleet. 2001. The future of readers' advisory in a multicultural society. In The readers' advisor's companion, ed. Kenneth D. Shearer and Robert Burgin, 249-67. Englewood, Colo.: Libraries Unlimited.

DeZelar-Tiedman, Christine. 1996. Subject access to fiction: An application of the Guidelines. Library Resources \& Technical Services 40 (3): 203-10.

EBSCO Information Services. 2002a. Bibliographic \& full text databases: NoveList. Accessed Jan. 25, 2003, www.epnet. com/public/novelist.asp.

— 2002b. NoveList: Best fiction. Accessed Jan. 27, 2003, http://novelst3.epnet.com/novel/levels.asp?pd=402326\&action $=$ Best + Fiction\&leveloffset $=11$.

- 2002c. NoveList: Notes January, 2002. Accessed Jan. 26, 2003, http://novelst3.epnet.com/novel/explore.asp?rd=590903.

- 2002d. NoveList: Subject headings. Accessed Jan. 26, 2003, http://novelst4.epnet.com/novel/nlc/search/Subject Headings.htm.

Flexner, Jennie M., and Sigrid A. Edge. 1934. A readers' advisory service. New York: American Association for Adult Education.

Frieband, Susan Jane. 1993. Developing readers' advisory service for library users whose primary language is not English. Collection Building 12 (3/4): 79-84.

Galloway, Gloria. 2003. Toronto most ethnically diverse in North America. The Globe and Mail (January 22): A6.

Garrison, Dee. 1979. Apostles of culture: The public librarian and American society, 1876-1920. New York: Free Press.
Harris, Michael H. 1973. The purpose of the American public library: A revisionist interpretation of history. Library Journal 98 (16): 2509-14.

Hayes, Susan M. 2001. Use of popular and literary criticism in providing subject access to imaginative literature. Cataloging o Classification Quarterly 32 (4): 71-97.

Herald, Diana Tixier. 2000. Genreflecting: A guide to reading interests in genre fiction, 5th ed. Englewood, Colo.: Libraries Unlimited.

Knutson, Gunnar. 1991. Subject enhancement: Report on an experiment. College \& Research Libraries 52 (1): 65-79.

Lagemann, Ellen Condliffe. 1989. The politics of knowledge: The Carnegie Corporation, philanthropy, and public policy. Middletown, Conn.: Wesleyan Univ. Pr.

Library of Congress. 2002. Library of Congress authorities. Accessed Dec. 2002-Jan. 2003, http://authorities.loc.gov.

Library of Congress. Cataloging Policy and Support Office. 1996. Subject cataloging manual subject headings, 5 th ed. Washington, D.C.: Cataloging Distribution Service, Library of Congress. . 2002. Library of Congress subject headings, 25th ed. Washington, D.C.: Cataloging Distribution Service, Library of Congress.

Lovell, Stephen. 2000. The Russian reading revolution: Print culture in the Soviet and Post-Soviet eras. Basingstoke, Hampshire: MacMillan.

Luyt, Brendan. 2001. Regulating readers: The social origins of the readers' advisor in the United States. Library Quarterly 71 (4): 443-66.

Massie, Allan. 2001. From hero to zero. [Review]. The Scotsman (July 21): 15.

Mehnert, Klaus. 1983. The Russians of their favorite books. Stanford, Calif.: Hoover Institution Press.

Nordemeyer, Ricki. 2001. Readers' advisory Web sites. Reference \& User Services Quarterly 41 (2): 139-43.

Olderr, Stephen. 1991. Olderr's fiction subject headings: A supplement and guide to the LC Thesaurus. Chicago: ALA.

Phelan, Laurence, and Lesley McDowell. 2001. Books: Paperbacks. [Review]. The Independent (July 29, 2001): 17.

Radway, Janice. 1991. Reading the romance: Women, patriarchy and popular literature. Chapel Hill, N.C.: Univ. of North Carolina Pr.

Random House. 1998. Modern library: 100 best novels. Accessed Jan. 27, 2003, www.randomhouse.com/modernlibrary/ 100best/novels.html.

Ranta, Judith A. 1991. The new literary scholarship and a basis for increased subject catalog access to imaginative literature. Cataloging \& Classification Quarterly 14 (1): 3-26.

Reference guide to Russian literature, ed. Neil Cornwell. 1998. London and Chicago: Fitzroy Dearborn.

Ross, Catherine Sheldrick. 1991. Readers' advisory services: New directions. $R Q 30$ (4): 503-18.

. 1995. "If they read Nancy Drew, so what?" Series book readers talk back. Library o Information Science Research 17 (3): 201-36.

- 1999. Finding without seeking: The information encounter in the context of reading for pleasure. Information Processing \& Management 35 (6): 783-99.

Saarti, Jarmo. 2002. Consistency of subject indexing of novels by public library professionals and patrons. Journal of Documentation 58 (1): 49-65. 
Sapp, Gregg. 1986. The levels of access: Subject approaches to fiction. $R Q 25$ (4): 488-97.

Saricks, Joyce G. 2001. The readers' advisory guide to genre fiction. Chicago: ALA.

Shearer, Kenneth D., and Robert Burgin, eds. 2001. The readers' advisor's companion. Englewood, Colo.: Libraries Unlimited.

Statistics Canada. 2002. Population by selected ethnic origins, Canada (2001). Accessed May 23, 2003, www.statcan.ca/ englihs/Pgdb/demo28a.htm.

Stelmakh, Valeria D. 1995. Russian reading in a period of social and cultural change. International Information \& Library Review 27 (1): 7-23.

- 1998. Reading in post-Soviet Russia. Libraries \& Culture 33 (1): 105-12.

- 2001. Reading in the context of censorship in the Soviet Union. Libraries \& Culture 36 (1): 143-51.

Tompkins, Jane. 1993. West of everything: The inner life of westerns. New York: Oxford Univ. Pr.

Trehub, Aaron. 2000. Slavic studies and Slavic librarianship in the United States: A post-Cold War perspective. Solanus 14: 91-108.

United Nations Educational, Scientific and Cultural Organization. 2003. Index translationum: International bibliography of translations. Accessed May 23, 2003, http://databases. unesco.org/xtrans/xtra-form.html.

United States Census Bureau. 1992. American fact finder: Profile of selected social characteristics: Education, ancestry, lan- guage and more: 1990. Accessed May 23, 2003, http:// factfinder.census.gov/servlet/BasicFactsServlet.

. 2002. American fact finder: Profile of selected social characteristics: Education, ancestry, language and more: 2000. Accessed May 23, 2003, http://factfinder.census.gov/servlet/ BasicFactsServlet.

Vesper, Virginia. 1997. The readers' advisor in academic libraries. Accessed Feb. 17, 2003, www.mtsu.edu/ vvesper/advise.html.

Watson, Dana. 2000. Time to turn the page: Library education for readers' advisory services. Reference \& User Services Quarterly 40 (2): 143-46.

Wertheimer, Leonard. 1991. Multiculturalism under siege: Where are the libraries? Canadian Library Journal 48 (December): 381-82.

Wiegand, Wayne. 1999. Tunnel vision and blind spots: What the past tells us about the present; Reflections on the twentieth-century history of American librarianship. Library Quarterly 69 (1): 1-32. . 2001. Missing the real story: Where library and information science fails the library profession. In The readers' advisor's companion, ed. Kenneth D. Shearer and Robert Burgin, 7-14. Englewood, Colo.: Libraries Unlimited.

Wilson, Mary Dabney, et al. 2000. The relationship between subject headings for works of fiction and circulation in an academic library. Library Collections, Acquisitions, \& Technical Services 24 (4): 459-65.

Wimmer, Natasha. 2001. The U.S. translation blues. Publishers Weekly 248 (21): 71-74.

\section{Appendix Source of Reviews}

\section{Dostoevsky's The Idiot}

Christian, Nicole, and Neil Cornwell, eds. 1998. Reference guide to Russian literature, 257-58. London and Chicago: Fitzroy Dearborn.

Magill Book Reviews/Magill on Literature. 2001. Electronic resource. Ipswich, Mass.: Ebsco Industries.

\section{Dovlatov's The Suitcase}

Adams, Phoebe-Lou. 1990. Brief reviews: The suitcase. The Atlantic (June): 120.

Christian, Nicole, and Neil Cornwell, eds. 1998. Reference guide to Russian literature, 261. London and Chicago: Fitzroy Dearborn.

Pekar, Harvey. 1991. The suitcase by Serge Dovlatov and translated by Antonina Bouis. Review of Contemporary Fiction (spring): 320-21.

Steinberg, Sybil. 1990. The suitcase. Publishers Weekly (Apr. 13): 54

Sweedler, Ulla. 1990. The suitcase. Library Journal (May 15): 93.

\section{Baranskaya's A Week Like Any Other}

Christian, Nicole, and Neil Cornwell, eds. 1998. Reference guide to Russian literature, 141-42. London and Chicago: Fitzroy Dearborn.
Kaganoff, Penny. 1989. Paperbacks: Fiction originals-A week like any other. Publishers Weekly (Sept. 15): 113.

Zirin, Mary F. 1990. Fiction: A week like any other. Library Journal (March 1): 113.

\section{Pelevin's The Life of Insects}

Baer, Joachim T. 1997. The life of insects. World Literature Today (autumn): 823.

Bernstein, Richard. 1998. Philosophical bugs in Russia? Quick, Ivan, the flit! New York Times (April 29): E9.

Caso, Frank. 1998. The life of insects. Booklist (Feb. 15): 983.

Dyer, Richard. 1998. Rising Russian star's wry animal allegory. Boston Globe (June 11): F8.

Falbo, M. Anna. 1998. The life of insects. Library Journal (February 1): 112.

Garner, Dwight. 1998. Flies like us. The Village Voice (February 17): 127.

Levi, Jonathan. 1998. The daily buzz of human existence: The life of insects. Los Angeles Times (March 16): 4.

Olcott, Anthony. 1998. Metamorphosis. The Washington Post (March 22): X4.

Paddock, Christopher. 1998. The life of insects. Review of Contemporary Fiction (summer): 236. 